\title{
Investigating the Effects of Dividends Pay-out on Stock Prices and Traded Equity Volumes of BSE Listed Firms
}

\author{
Ishmael Radikoko, Emmanuel Ndjadingwe
}

\author{
University of Botswana, Gaborone, Botswana \\ ${ }^{1}$ Corresponding Author's Email: ishmael.radikoko@mopipi.ub.bw
}

\begin{abstract}
The main objective of this study is to examine the effect of dividend pay-out on the prices of stock in Botswana's equity market as well as the effect of traded volumes of such stocks. Other objectives of the research are to determine the optimal pay-out ratio based on the profits of the firm and to determine the optimal time to declare and pay dividends. We use quota-sampling technique and selected 5 companies from the 22 domestic listed companies in the Botswana Stock Exchange. The companies under consideration are Barclay Bank, RDCP, Chobe, Engen and Sefalana Plcs. These companies are chosen based on the availability of daily closing trading information for the past five years and easiness to get information to use for our study that includes dividends pay-outs, profits made, volumes traded, etc. The result of this study reveals that there is a direct relationship between dividend announcement, ex-dividends, dividend pay-out ratio and volume of stock traded and the stock price in Botswana. Furthermore, the study concludes that there is a direct relationship between change in dividends and change in dividend per share. Lastly, the finding reveals that most of the companies sampled pay dividends between December and March. We recommend that companies should have an optimal dividend policy as this have been proven to increase firm value. We also recommend that firms should announce dividends around December to March to counter the end of year effect that usually suppresses stock prices.
\end{abstract}

Key words: Dividends, Dividend-Pay-out ratio, Traded Volumes and Equity Prices

\section{INTRODUCTION}

Nobel Prize winners Miller and Modigliani (MM) (1958) first coined a breakthrough theory on dividends that sparked the popularity and significance of dividend policy on corporate finance decisions. The debate over the significance or insignificance of dividends had since started to this day (McGowan, 2005). This area of study has divided the corporate finance scholars into three schools of thought over time. The first being proponents of Miller and Modigliani's (1958) dividend irrelevance theory. This school of thought hold the view that whether the firm pays dividends or not, that does not influence the value to the firm. The second school of thought believe that dividends are relevant in investors' decision making, and, therefore, their payment or non-payment has an impact on firm value. The third group of scholars believe that to determine the relevance or irrelevance of dividend on firm value, a few questions must be answered, like who they matter to and why, the type of investors, income levels and investment scopes. The latter school of thought further argue that since every type of investor has different investment horizons, their views on dividends may differ. Other subsequent studies on this subject brought about other theories supporting or disputing MM's dividend irrelevance theory. These include The Bird in a Hand Theory by Litner and Gordon (1963), Tax Preference theory by Litzenberger and Ramaswamy (1979). Other theories include the Clientele Theory, the Signalling Hypothesis as well as, Self-made Dividends and Residual Dividends Theories as the most recent ones.

General observation reveals that a large number of companies all over the world continue to pay the dividend, yet, they are not obliged to do so. There is a question "why". Why do they choose to distribute cash to investors instead of investing and expanding their operations? Sharma (2011) ascertains that they pay because dividends are an added boost for investors to want to keep a certain stock in their portfolios since dividends have information content and can also provide liquidity for investors if they are significant enough. However, given opposing different schools of thought on dividends and their effects on firm value remains uncertain as to whether dividends really matter in investment decision making. Moreover, concerning Botswana's market, limited or no literature exist which shows how Botswana stands in terms of effect of dividends pay-out on firm values and traded volumes of shares. Other aspects like optimal dividend pay-out ratio and timing of dividends pay-out also remain a mystery with regards to Botswana's stock markets. 
Therefore, taking cue from the above discourse, in this paper, we focus on Botswana's stock markets and investigate particularly the effect of dividends pay-out on stock prices and traded volumes of Botswana Stock Exchange (BSE) listed firms. Furthermore, we look at other important dividend policy issues like how much dividends firms pay and when do most firms declare and pay dividends? This study contributes significantly to the field of corporate finance by providing empirical evidence from BSE regarding the optimal pay-out ratio and the optimal timing of declaration and payments of dividends.

More specific objectives of the study are outlined as follows:

- To investigate whether dividends influence the volume of trading and stock price - This will be assessed by analysing volume and value of stocks traded some days before and after declaration and exdividend date;

- To investigate the optimal pay-out ratio based on the profits of the firm - This will be determined by analysing the pay-out ratio of successful firms in terms of profitability and share price and compare it to that of low performing firms;

- To investigate the optimal time to declare and pay dividends as well as to take advantage of or mitigate the negative effects of seasonality like the market anomalies (January effect e.g.);

- To fully understand dividend policy and we clarify some common concepts before embarking on our study that include dividend declaration and payment, ex-dividend date, pay-out ratio and timing and seasonality of dividends.

Firstly, dividend policy refers to how management decide to distribute firm profits between retention and payment to shareholders (Lease et al., 2000; Al-Malkawi, Rafferty and Pillai, 2010). Therefore, the firm always has three alternatives on how to make this distribution: it can distribute all their earnings as dividends, or retain all their earnings or retain a portion of earnings and distribute the rest to shareholders. This leads us to a concept of pay-out ratio, which means the proportion of profits which is distributed to investors as dividends. Before the firm pays dividends, it will have to announce a future date on which it will pay dividends. This announcement date is the dividend declaration date while a future date on which dividends will be paid is the payment date. Another concept is the ex-dividend date, which is the date after which the investor will not be legible to receive dividends if he/she buys shares. The final concept, which will be studied in details on this paper, is seasonality and timing of dividend payment and declaration. This study simply tries to explain whether companies follow certain trends and date to pay their dividends. It also ascertains whether there is a best period to pay/declare dividends. Lease et al. (2000), Allen and Michaely (2002); Baker (2009) and Al-Malkawi (2010) provide excellent surveys of dividend policy literature.

The rest of this paper is composed as follows. In the next section, section two, we review related literature for the topic under investigation. This will be followed by methodology employed in this study (section three), which will lead to description and analysis of data, findings and discussions. We wrap up our study by giving concluding remarks and recommendations which appear in section four and five respectively.

\section{REVIEW OF RELATED LITERATURE}

Since the breakthrough theory on dividends by Modigliani and Miller (1958), there has been an argument in literature as to whether dividends really matter in affecting firm value and traded volume of shares. After studying 20000 firms over a period of 20 years, Xu et.al. (2002) concluded that public announcements on dividends are always accompanied by abnormal trading activity due to their preannouncement disagreement and after-announcement agreement theory. The latter theory states that investor disagree before the announcement of dividends and agree afterwards. This means that investors will always have different perspectives upon announcement; there are those viewing it as a positive signal and those seeing it as a warning sign. These differing perspectives are what lead to abnormal trading, as some investors call and others put, hence, causing the abnormal trading volume and prices. This clearly indicates the signalling effect of dividend announcement disputed by a study of Capstaff, Klaeboe \& Marshall (2004) which states that the signalling effect of dividend is very scarce. After announcement, prices are expected to stabilise as new information has now been incorporated in the stock price. Bajaj and Vijh (1995) also support the information assimilation view by showing that there is a lot of information generated around the announcement period. Therefore, abnormal trading and excess returns are attributed to dividend information. In a study by Yang and Wu (2014), focusing on exdividend dates, empirical evidence from Taiwan shows that investors who buy stock 11 days before the ex-dividend date and sell ten days after the ex-dividend date obtain an average of $2.13 \%$ abnormal returns net of transaction costs. This view is consistent with a study by Yang and Wu (2004) which provide empirical evidence saying that ex-dividend trading brings abnormal returns of $2.07 \%$ while that an increase in cash dividend has abnormal returns of $1.96 \%$. However, cash dividend decrease does not have a negative impact as some studies suggest, in the same study, $0.48 \%$ abnormal returns were recorded after a decrease in the amount of cash dividends. 
Bajaj and Vijh (1995) attributed these abnormal gains to incremental risk around this period. They further state that trading volume increases by 0.084 during the announcement period, with a positive correlation of 0.594 to risk; the risk level is expected to rise. Therefore, it is known that higher risk attract higher returns, hence, bringing abnormal returns during this period to compensate investors. Yang and $\mathrm{Wu}$ (2014) study the relationship between dividend pay-out ratio (DPOR) and cumulative abnormal returns. Their results showed that firms with DPOR $<50 \%$ had average abnormal returns of $1.74 \%$ while those with $\mathrm{DPOR}=>50 \%$ experienced cumulative abnormal returns of $2.24 \%$. This is contrary to the norm because finance theory tells us that if fewer dividends are paid it means a large portion of earnings are retained and expected to contribute to high growth in the company and hence, the returns associate with investing in its equity securities.

Study by Baker, Chang, Dutta, \& Saadi, (2012) on why firms do not pay dividends proposed the following constraints: smaller firms size, low profitability, low cash reserves and greater growth prospects. Therefore, it is common to find larger and more profitable firms paying more dividends and having high pay-out ratios.

There is not a lot of study focusing on market anomalies and seasonal timing of dividends. However, one of the studies conducted on dividend timing by Bulan, Subramanian and Tanlu (2007) state that in relation to firm life cycle, firms usually pay dividends at the maturity stage due to greater profitability and excess cash flows. This is consistent with Baker's et al. (2012) conclusion. It is a common norm in business to announce bad news latest or end of the week, and to make positive announcements earliest. This is usually done to control the rate information at which the market act on. Dividends may be bad news or good news to different people, so when does the firm make such an announcement?

A study by Bajaj and Vijh (1995) documents that investors realise positive excess returns during the period of dividend declaration. They also observed high volatility of stock prices and volume of trading during this period after studying daily closing prices and transactions data. They concluded that this excess return could not be attributed to measurement errors but rather to the assimilation of dividend announcement information into the stock price. This is because of information value of dividends, the signalling effect and the market efficiency theory: whenever new information is released, the prices have to change to reflect and incorporate this information in the stock prices. The speed of this incorporation is subject to the efficiency of the market.

Concerning Botswana, there is limited or no literature in relation to the effect of dividends on firm values and traded volumes. Moreover, there is no empirical evidence that can provide a basis for a firm to choose optimal pay-out ratio so as to maximise share values. Furthermore, due to lack of supporting literature it remains unknown when is the right time for a firm to declare dividends to enhance company equity value in Botswana. It is on this background that we engage in this research to uncover these unknown aspects about dividends in Botswana.

However based on literature from other countries around the world as stated in this paper and the fact that stock markets are assumed to be efficient, it is reasonable to make an informed guess that dividend declaration will have a positive impact on stock prices, and volume of trading of BSE listed stocks. This is because the stock price must change to incorporate new information (EMH by Fama, 1970). Therefore, the expectation is that stock volumes traded and prices should peak around dividend declaration date. Contrary to MM's dividend irrelevance theory, we also hypothesize that dividends policy does matter in Botswana. Since market anomalies like the January effect and day of the week effect have been found to have an impact on stock prices, then it can be concluded that they may also influence the firms' timing of dividends to get the best positive price and volume volatility. We, therefore, hypothesize that the trading volumes and prices will rise upon declaration of dividends and that companies will declare their dividends in times that will minimise the end of the year and the January effect anomalies that usually are associated with low stock prices.

\section{METHODOLOGY}

\subsection{Source of Information and Sampling Method}

The Botswana's equity market as represented by Botswana's stock exchange (BSE) has 34 companies trading in BSE platforms as in April 2015. The domestic companies make a large part of the market with 22 listed firms. The remaining 12 companies are foreign companies with a primary listing in other stock exchanges around the world. In addition to the main equities traded in the BSE, the market has also introduced three Exchange Traded Funds (ETFs) in an effort to increase the number of products available in the equity market.

In this study, we focus only on the 22 domestic companies listed in the BSE. These companies form the domestic companies index (DCI) of the BSE. We exclude foreign firms in our study due to some variables 
that are difficult to monitor their influence on dividend policy. These variables include country's economic growth, foreign exchange risk, political risk and corporate governance and control of these foreign firms. We also exclude the ETFs in our analysis since the three ETFs that are in BSE are secondary listed and are foreign, mainly primary listed in the Johannesburg stock exchange of South Africa (JSE) and hence, are exposed to the same variables mentioned earlier. The quota sampling method is used, where the 22 listed domestic companies are divided into five categories according to industries (see figure 1 below). From each category/industry, one company has been selected. This results in a total of five companies chosen for this study. These are Barclay Bank, RDCP, Chobe, Engen and Sefalana Plcs. These companies are chosen based on the availability of daily closing trading information for the past five years. The analysis is on each company's daily trading closing information from January 2010 to December 2014. The five-year period helps determine the trend of the effect of ex-dividend trading on volume and stock price because the time frame is wide enough to paint a graphical picture of how the stock price and volume are influenced by dividend announcement and ex-dividend trading as well as making generalisation reasonable. The daily trading closing information is available on the Botswana Stock Exchange website for all listed entities. It shows the volumes traded for all stocks every trading day and the closing prices. The sampled companies in this study also publish their annual financial reports on the BSE website, and they are available for download. These reports further provide insight on sample firm profitability and their dividend policy.

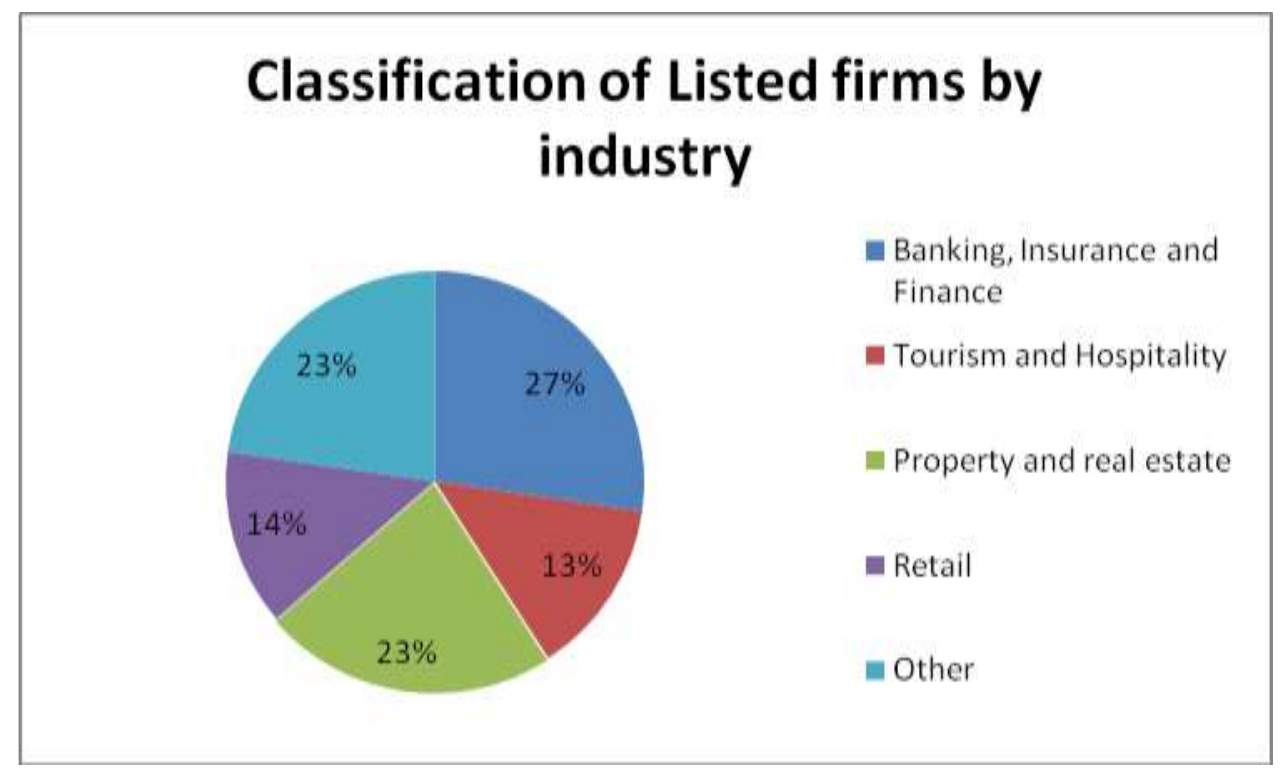

Figure 1: Classification of BSE listed Firms by Industry

\subsection{Processing of Information}

Daily trading data 10 days before and after dividend announcement date is analysed for each sampled company to determine the effect dividend declaration have on volumes of stocks traded. Trading data is obtainable from BSE and company reports. This analysis is across the five-year time frame and plotted on a graph to have a better view of cyclical occurrence for each company. The share price is plotted against time within the same period to determine whether trading on this period has a significant influence on the share price. In addition, net profits are also observed in relation to the amount of dividends declared. The correlation coefficient of this latter relationship is also computed to determine the strength and direction of this relationship. Dividend announcement dates are also observed to determine whether they follow a certain trend across the year, concentrated at some period or just randomly distributed.

\subsection{Analysis of Data, Discussions and Findings}

Market data from BSE between January 2010 and December 2014 is analysed for each of the companies in the sample and the information encompasses the daily closing prices and volumes of stock traded. According to Efficient Market Hypothesis (EMH), changes in stock prices are usually due to random and coincidental occurrences but the extent of this random walk factors cannot be determined with absolute certainty. In this study, ceteris paribus, we assume that all abnormal trading and price changes that take place around announcement and ex-dividend date are influenced by dividends' information content. Since random factors and market anomalies are difficult to predict and measure, we assume that all changes in prices and volume observed on the study are dividend effects. Further, we present the findings of our analysis. 


\subsubsection{Net profit and Dividends analysis}

We start with the determination of the relationship between profitability and the level of dividends declared by each company. The changes in net profit and dividend declared for the past five years for each sample company are computed and plotted on a graph to observe their graphical relationship over time.

Figures 2 to 6 - Net Profit and Dividends Relationship-Barclays below indicate that changes in profitability and dividend varied together in the same direction. We also present computed correlation coefficients (denoted as $r$ ) for changes in net profits and changes in dividends declared to show the strength of this relationship. Since we assume that changes in traded volumes and stock values are purely results of dividend information content, we do not compute the coefficient of determination (R2) nor do we compute the adjusted R2. The results show that strong positive correlations are noted between net profit and changes in dividends declared for all companies under investigation. In particular, figure 2 shows that there is a positive correlation between Barclays' changes in net profit and change in dividend per share with a correlation coefficient of 0.59. Figure 3 shows that there is an almost perfect correlation between net profit and dividends for RDCP with a correlation coefficient of 0.93 . A correlation coefficient of 0.87 is observed for Chobe as shown in Figure 4, whilst figure 5 and 6 show weaker correlations of 0.43 and 0.10 for Engen and Sefalana respectively.
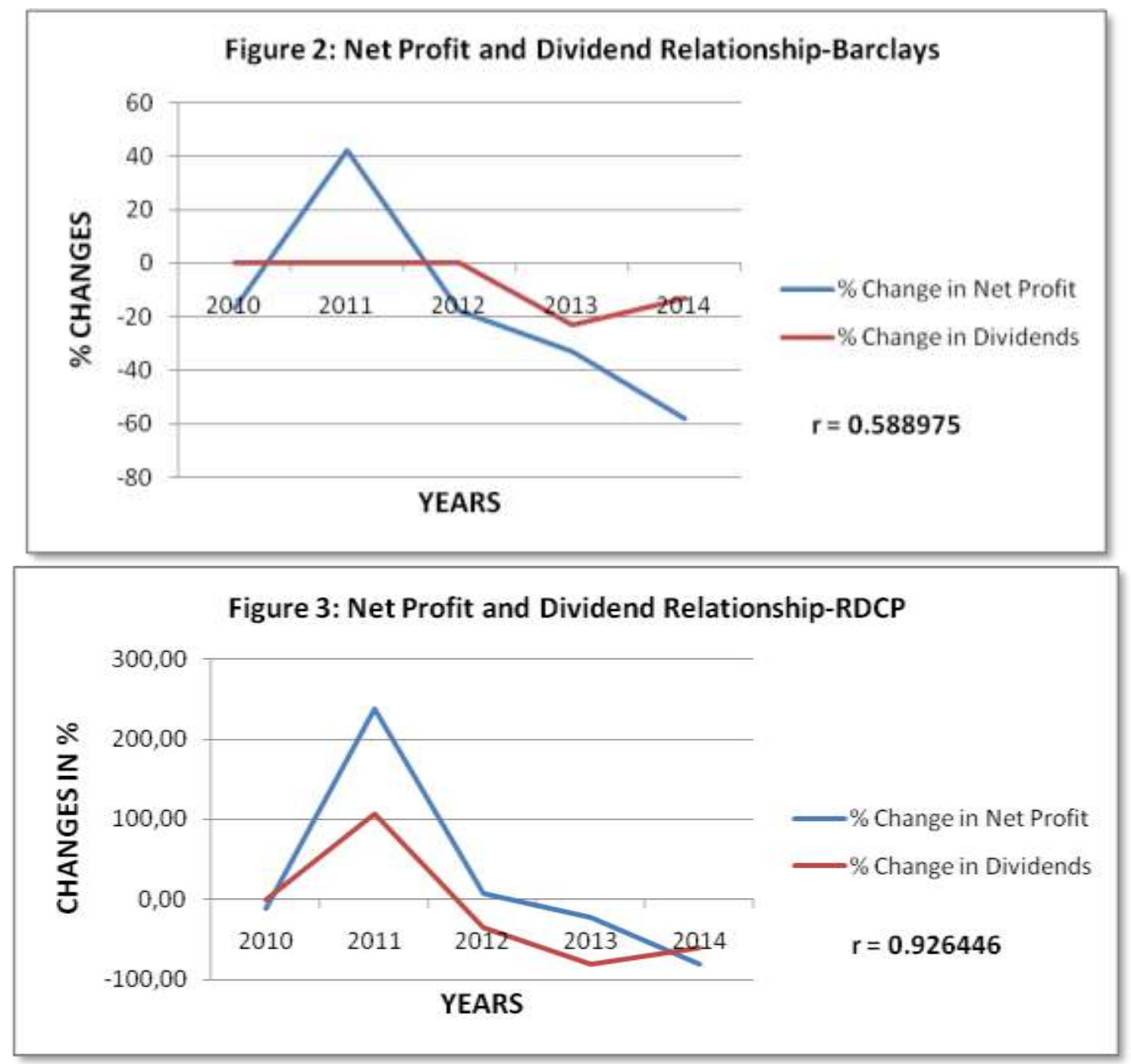

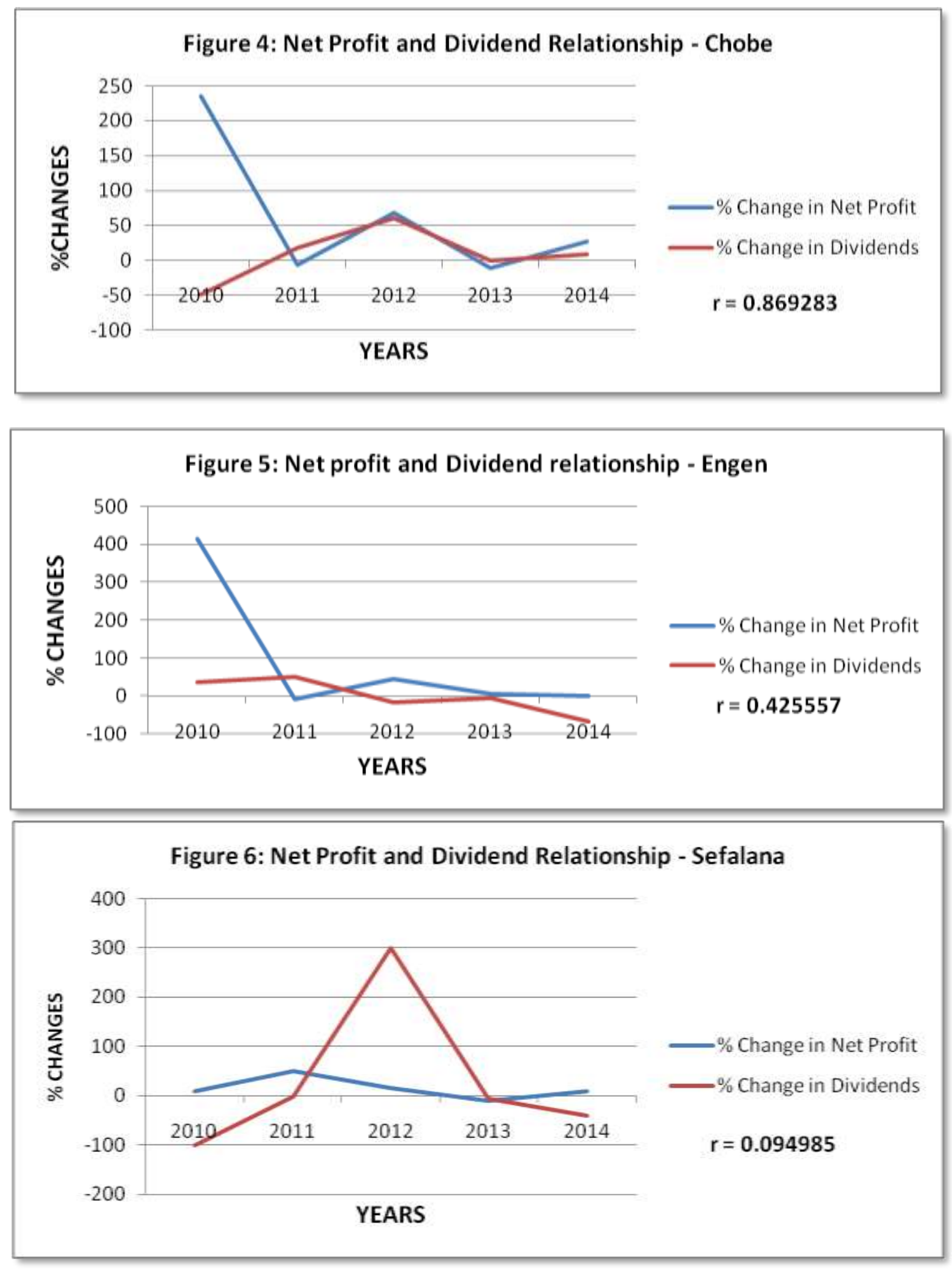

In sum, the results show that there is a positive relationship between dividends declared and net profit with an average correlation coefficient of 0.4633 . The results provide the basis to say that if net profit increases, companies are expected to increase their dividend pay-out and the reverse shall also hold.

\subsubsection{Pay-out ratio}

In this section, we analyse the level of pay-out ratio of our sampled firms to check whether dividend pay-out ratio has any effect in the price and hence the returns of the company. To do this, the pay-out of top 5 performing stocks in BSE are compared to the five poor performing stocks in 2014. According to Yang et al. (2014), there is a relationship between these variables. Firms with a higher pay-out ratio tend to outperform those with a lower ratio. Table 1 below present the pay-out ratios and associated equity returns for the respective companies 
Ishmael Radikoko, Emmanuel Ndjadingwe

Investigating the effects of dividends pay-out on stock prices and traded equity volumes of BSE listed firms

Table 1: Comparison of pay-out ratio and performance of companies in terms of returns

\begin{tabular}{|l|l|l|}
\hline Top 5 Performing stocks in term of returns \\
\hline COMPANY & PAY-OUT RATIO (\%) & RETURN (\%) \\
\hline Sechaba & 75.2 & 40.9 \\
\hline Chobe & 63 & 32.9 \\
\hline Sefalana & 36 & 30.2 \\
\hline G4S & 115.5 & 21.3 \\
\hline Wilderness Holdings & 69 & 18.3 \\
\hline Bottom 5 Performing stock in term of returns & \\
\hline Olympia & 0 & 0 \\
\hline FSG & 28.5 & 4.7 \\
\hline New African Properties & 4.1 & 6.34 \\
\hline Standard Chartered & 54.3 & 7.33 \\
\hline Engen & 60 & 9.8 \\
\hline
\end{tabular}

Based on the table above, generally companies with a higher pay-out ratio perform better than those with a lower ratio. There are two outliers in this study as highlighted in the table. Sefalana has a low average pay-out of $36 \%$ and was the third top earner. On the other side, Engen had an average pay-out ratio of $60 \%$ and yet it is one of the lowest performers. These results are consistent with views by Yang et al (2014), who observed that firms with a dividend pay-out of less than $50 \%$ experienced abnormal returns of about $2 \%$. The study concludes that generally firms with a higher pay-out ratio tend to outperform those with a lower ratio.

Another area of interest in our study is to find out the effects of dividend announcement and ex-dividend trading on volume traded and stock price. First, let us look at the effect of announcement on volume and stock price.

\subsubsection{Dividend announcement analysis}

According to Fama (1970) efficient market hypothesis, the stock market must adjust whenever new information is released in the market, such that the current price incorporates new information. The level of efficiency will determine the speed at which this information reaches investors and how fast they act upon it. Figure 8 shows that after Barclays' declaration date $(t=0)$, trading occurred normally until $t+10$, when an abnormal volume of stock was traded. This reflects the incorporation of new information; payment of dividends later. This also reflect the speed at which such information reach the investors or they react to it. However, no significant price change was noticed during the same period as shown in the same figure 8 below.

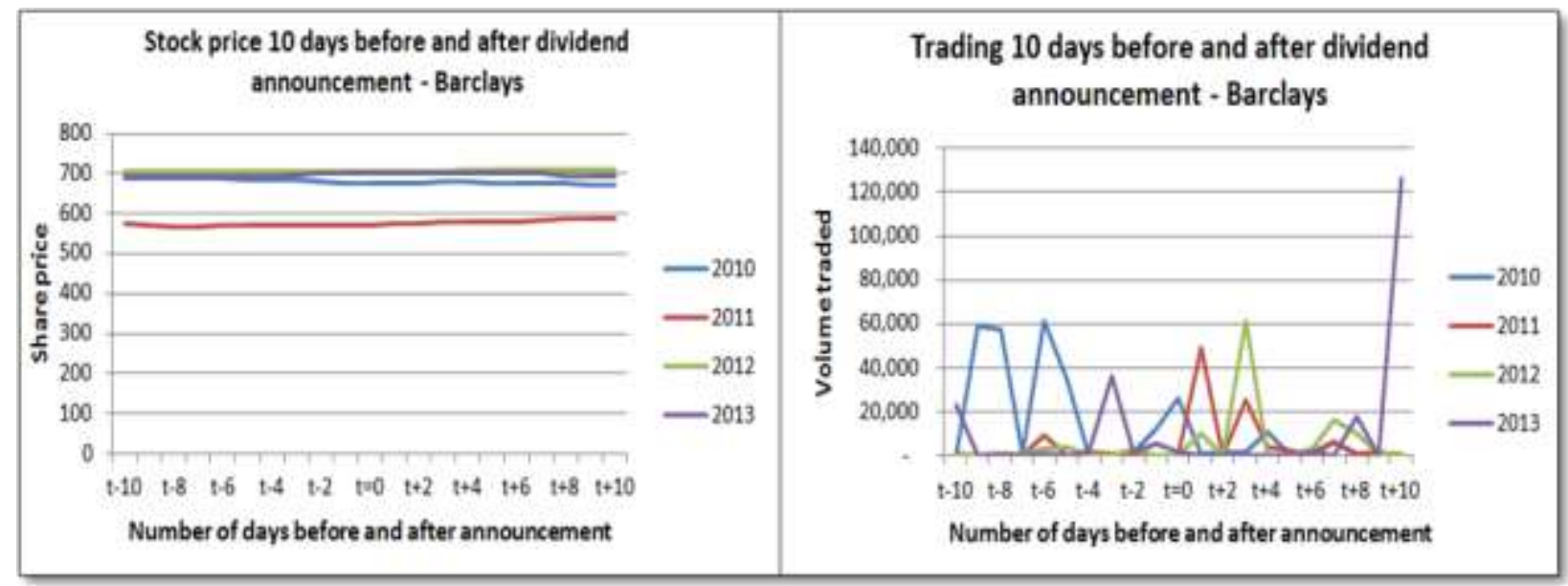

Figure 8: Stock Price and Traded volumes before and after dividend announcement dates for Barclays

As for RDCP, it turns out that there is no significant trading of its shares around the announcement date. This is revealed by figure 9 below which shows that between 2009 and 2012, there was no significant trading of share before and after dividend announcement. The only exception was in 2011, where the highest traded volumes were recorded about four days prior to the announcement. However, we can conclude that generally there is no direct relationship between dividend announcement and traded 
volumes for RDCP. A close look at figure 9 below reveals further that for the period under investigation there was no change in share values because of divided announcement. This does not come as much of a surprise because market information indicate that property stocks generally do not experience volatile, frequent and high volume trading as investors generally hold such stocks for some time in order to generate high capital gains in the long run.

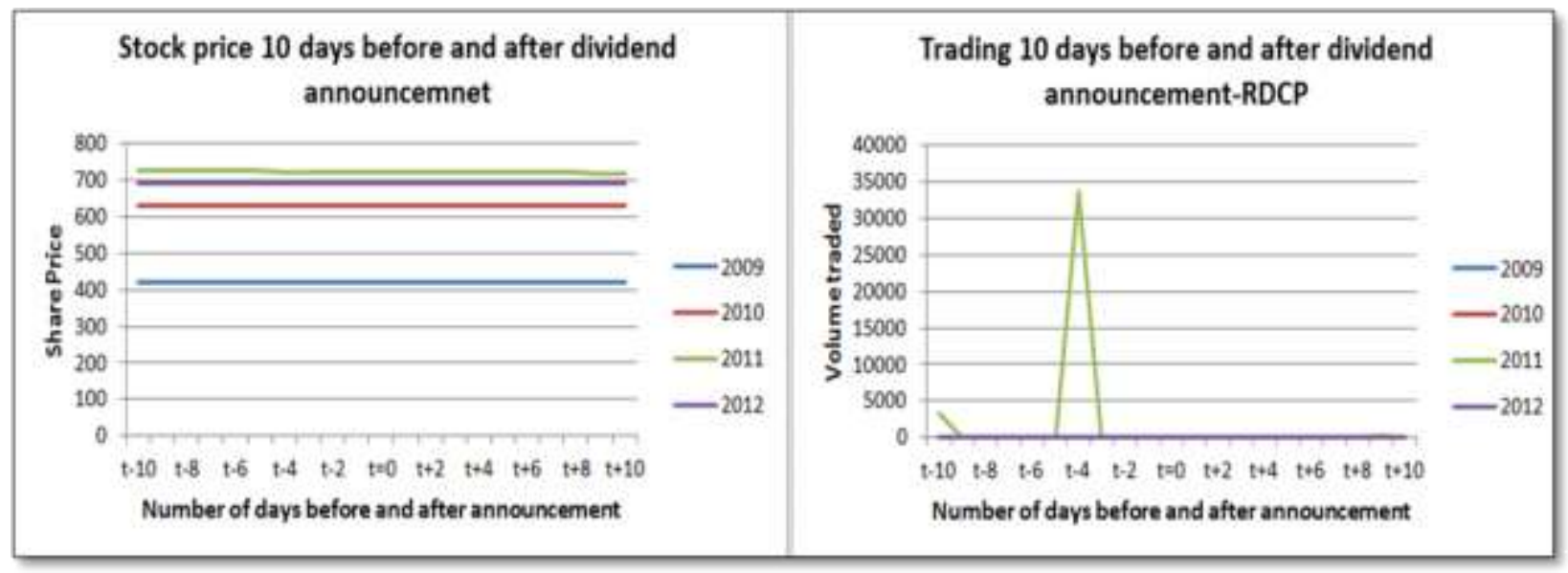

Figure 9: Stock Price and Traded volumes before and after dividend announcement dates for RDCP

Further, we present the behaviour of Chobe stock in reaction to dividend announcement. Starting with traded volumes, figure 10 below shows that Chobe stock is heavily traded after the dividend announcement. These findings corroborate with Fama (1970)'s view that investors act on new information in the market which can lead to increased traded volumes. However, there were no noticeable gains realised in this period due to the improved liquidity of the stock as prices remained the same, except for a marginal decline noticed at $t-4$ and $t+6$ in 2011.

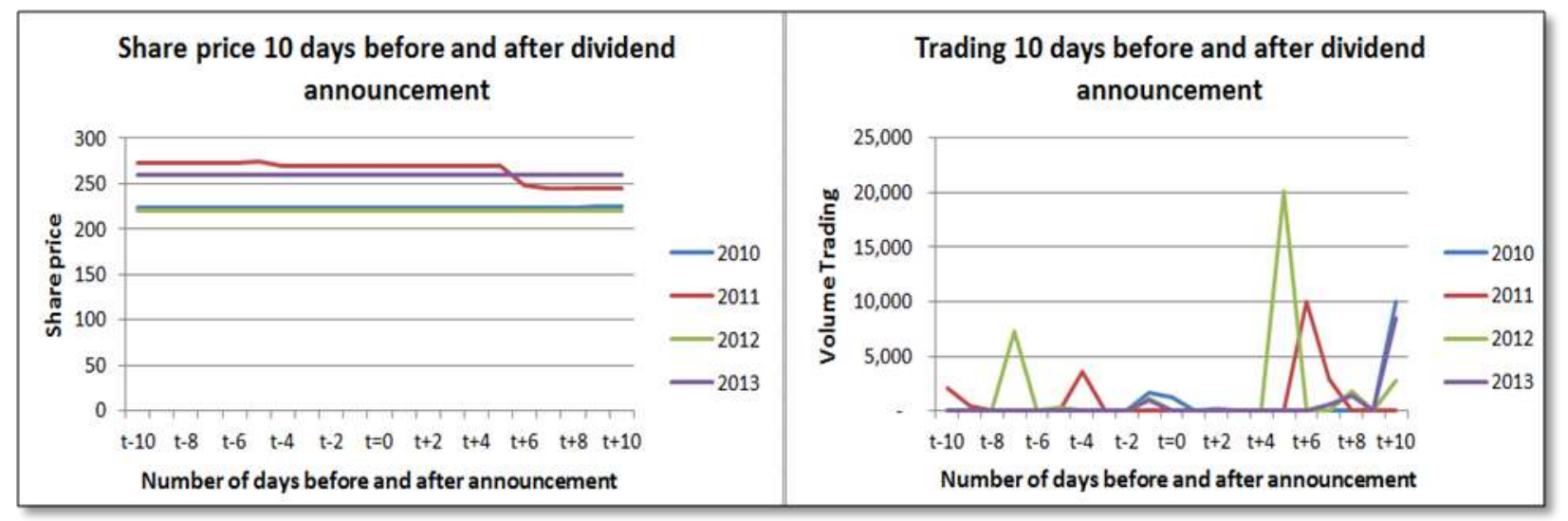

Figure 10: Stock Price and Traded volumes before and after dividend announcement dates for Chobe

Moving now to analysis for Sefalana, figure 11 below shows that there is abnormal trading volume few days prior to dividend announcement, and the volume decline after announcement date from $t=0$ onwards as shown in Figure 11. Concerning stock prices, for a larger part of the period under investigation, the stock price remains constant despite changes in traded volumes. The only noticeable change in stock price is observed in 2013. 


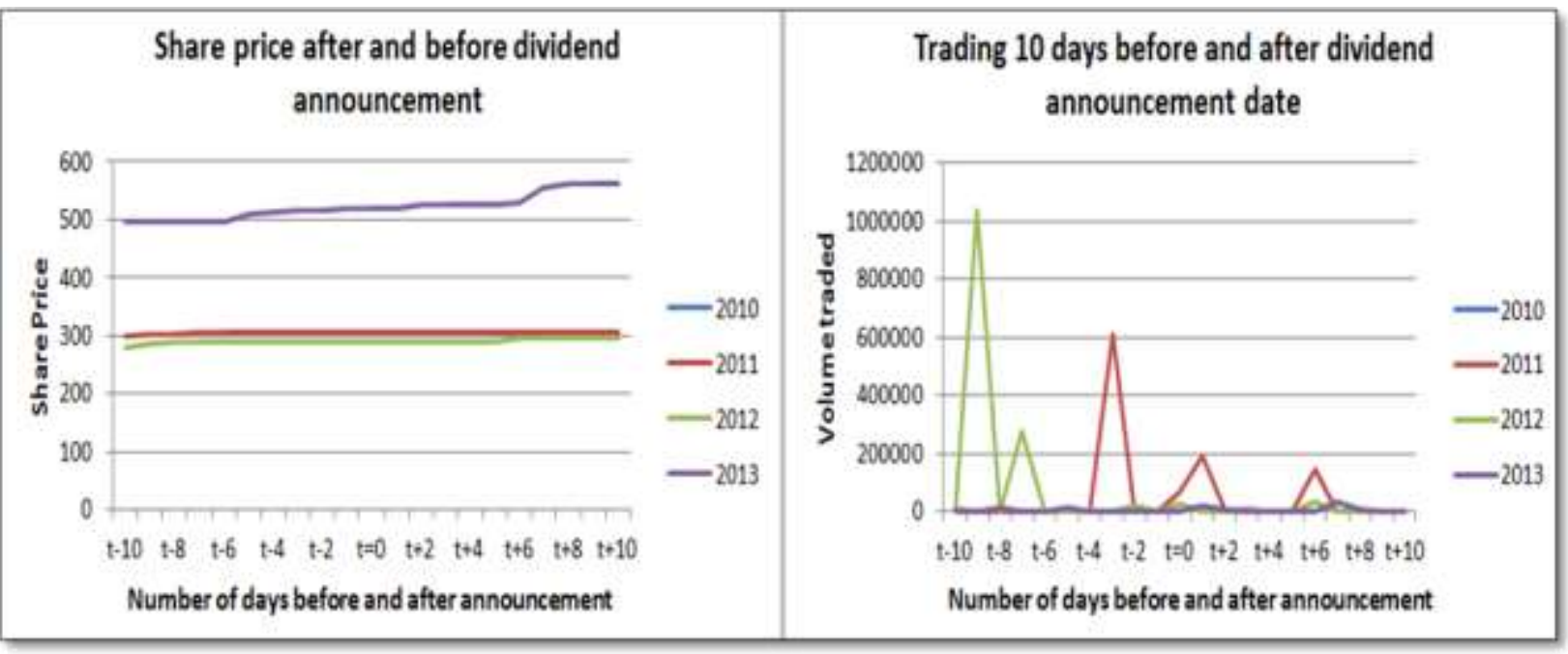

Figure 11: Stock Price and Traded volumes before and after dividend announcement dates for Sefalana

Lastly, we present the analysis for Engen stock around dividends announcement date. Figure 12 below shows high volume trading of Engen stock few days before and after dividends announcement. The preannouncement hype can be attributed to the fact that the company has been observed to announce dividend on the same day of each year. Therefore, some investors maybe anticipating that. Stock prices remain the same during the high trading period with a slight increase in stock price observed after dividend announcement usually from $t+6$ through $t+10$.

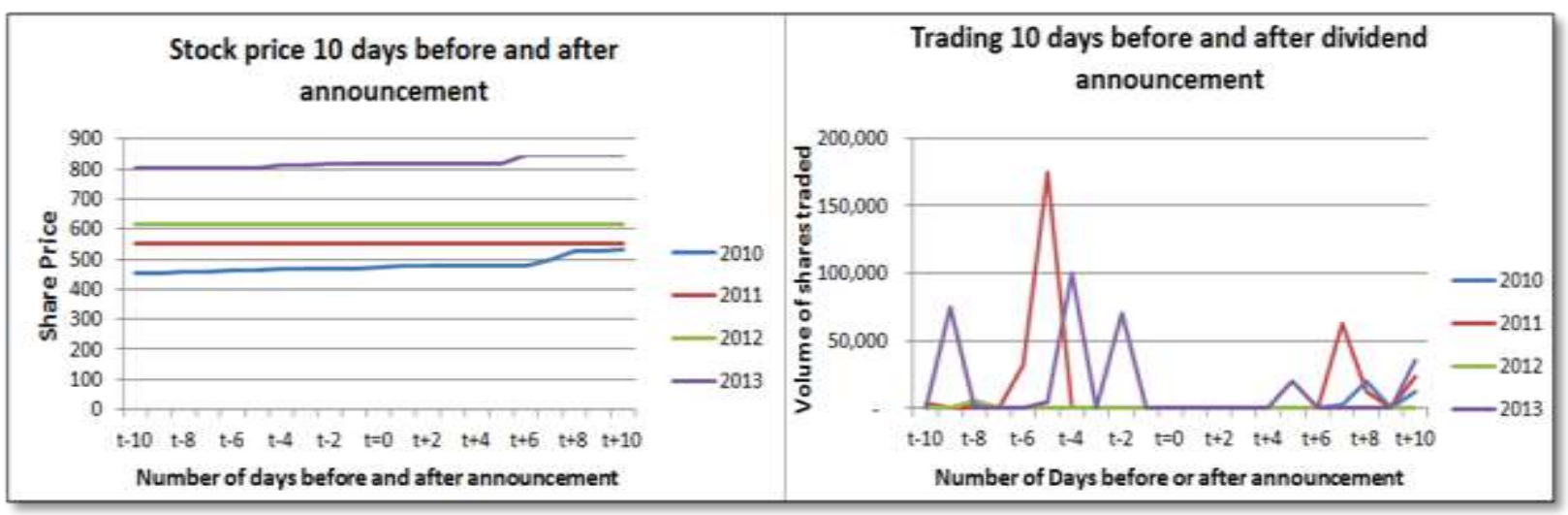

Figure 12: Stock Price and Traded volumes before and after dividend announcement dates for
Engen

In summary, the results of dividend announcement effect presented above show that there is a significant change in volume of stock traded around the dividend announcement date. This is an affirmation of the efficient market hypothesis, which state that whenever new information reaches investors they will decide to or not to act upon it. Therefore, it is clear that dividend influence the investors to act whenever they are announced. Results also show that after $t=0$, no price decline was recorded for any of the companies. However, significant price increases were recorded for some companies in some years for the period under investigation. These findings provide a preliminary support that dividend announcement is positive information that influences investors to buy and, to a lesser degree, drive prices on the stock up. These findings are consistent with the empirical evidence presented by Capstaff, Claeboe and Marshall (2004) who observed positive returns for stocks on the day of dividend announcement.

\subsubsection{Ex-dividend date analysis}

In this section, we examine the ex-dividend date and its effects on the value of stock and volume of trading. We present the results in the same manner as we presented above when investigating the dividend announcement effect on volumes and prices of stocks. We start with a graphical representation of Chobe stock behaviour in terms of traded volumes and price before and after the ex-dividend date. The figure below (figure 13) shows that there is abnormal trading of Chobe stock towards the exdividend date, $t=0$. This indicates that people acquire the stock to position themselves for dividends. This 
increase in trading is accompanied by an increase in stock price during the same period. At $t+6$, abnormal trading is observed again, which mean that dividend investors were maybe selling off the stock since they are now eligible for dividends.

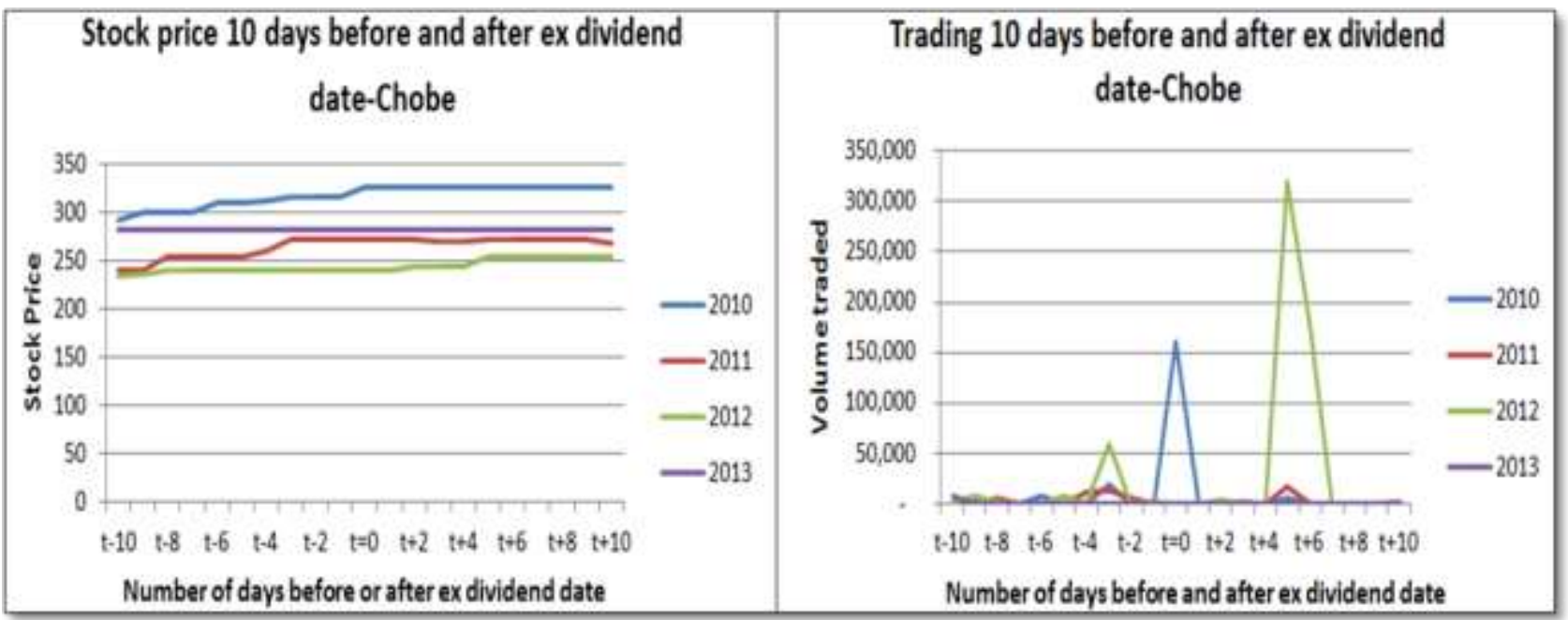

Figure 13: Stock Price and Traded volumes before and after ex-dividend dates for Chobe

Further, we move to the analysis for RDCP as presented in Figure 14 below. As per the figure, there is a peak in volume traded at t-2 occurred in 2013. This might suggest that investors buying at this period are eyeing dividends and registered shareholders by the time dividends are paid. The figure also shows that after $\mathrm{t}=0$, trading goes down to a normal level as expected. Low trading of shares was noticed in 2011 in the period under investigation and despite low traded volumes there was a significant increase in stock price during this period through 2013.

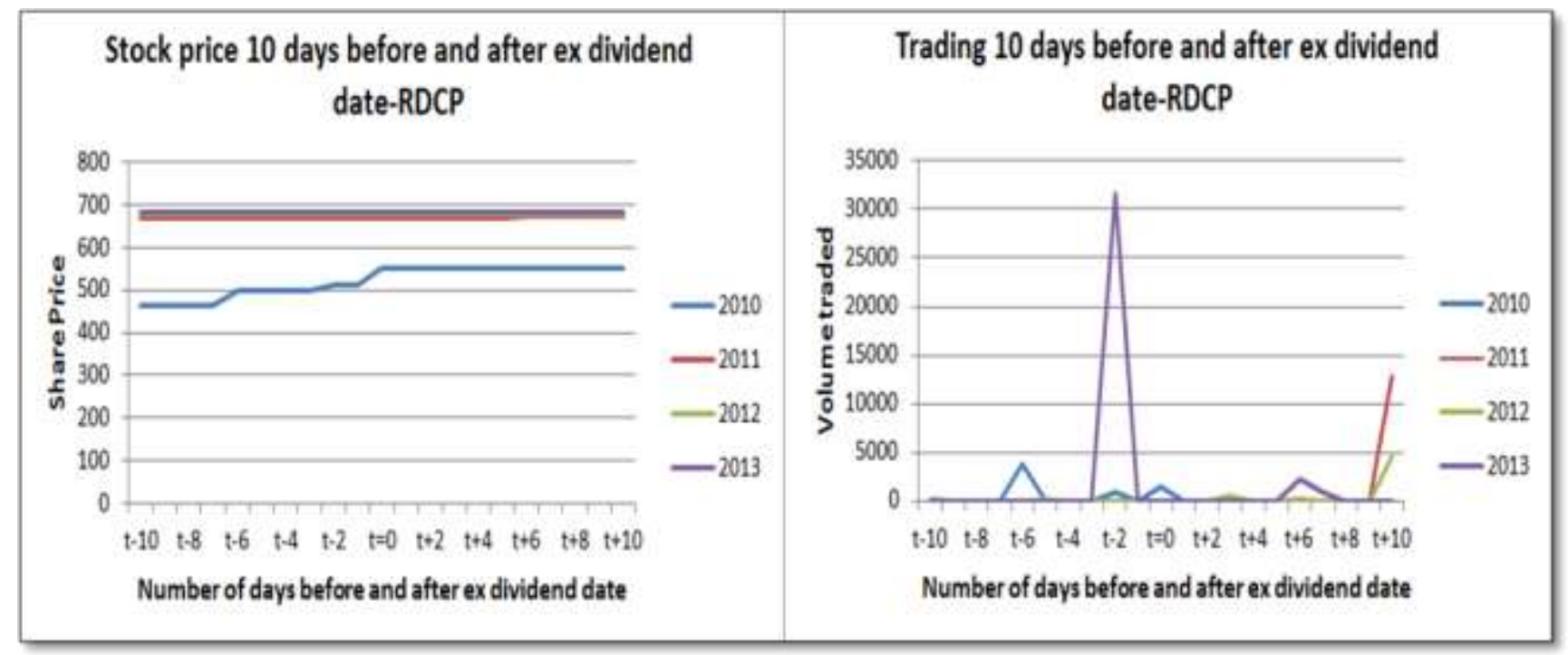

Figure 14: Stock Price and Traded volumes before and after ex-dividend dates for RDCP

As for Sefalana stock, our results reveals that the stock has been heavily traded at $t-7$ towards $t-0$ as shown in Figure 15 below. Despite high volume in 2011, no gains were released as stock price remained flat during that period. However, 2013 saw significant price increases before $t=0$ accompanied by some significant volume changes. After $t=0$, there was more volatile trading especially during 2011 and 2013 although there is no price change to suggest that dividend investors were disposing of the stock. 


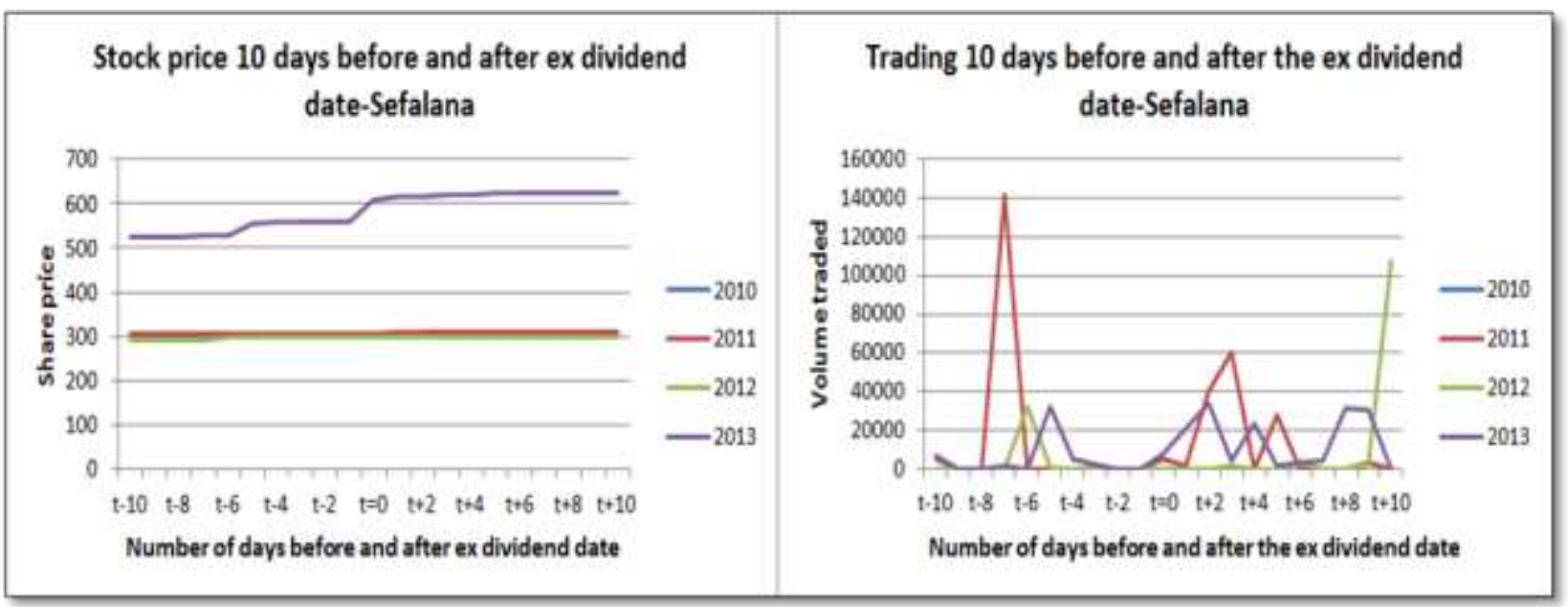

Figure 15: Stock Price and Traded volumes before and after ex-dividend dates for Sefalana

The ex-dividend date of Barclays also showed a significant change in volumes traded before and after $t=0$. However, the trading was not accompanied by any significant price changes except a decline in 2010 after $t+0$. The study attribute to sell off by investors who are registered and ready to receive dividends. Figure 16 is a graphical presentation of this information.

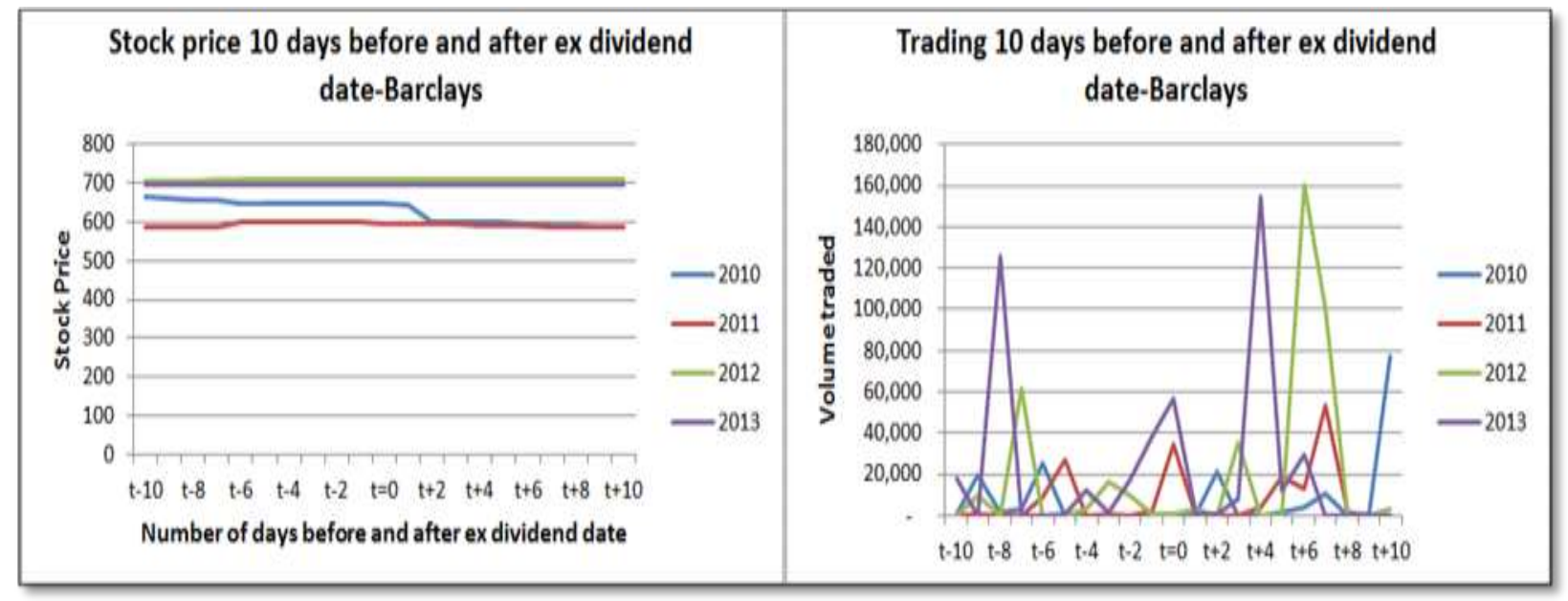

Figure 16: Stock Price and Traded volumes before and after ex-dividend dates for Barclays

The final observations on figure 17 were made on Engen to assess whether investors responded to dividend trading or not. There were random peaks of trades before and after $t=0$. The 2012 and 2013 peaks were accompanied price increases before and at $\mathrm{t}=0$.

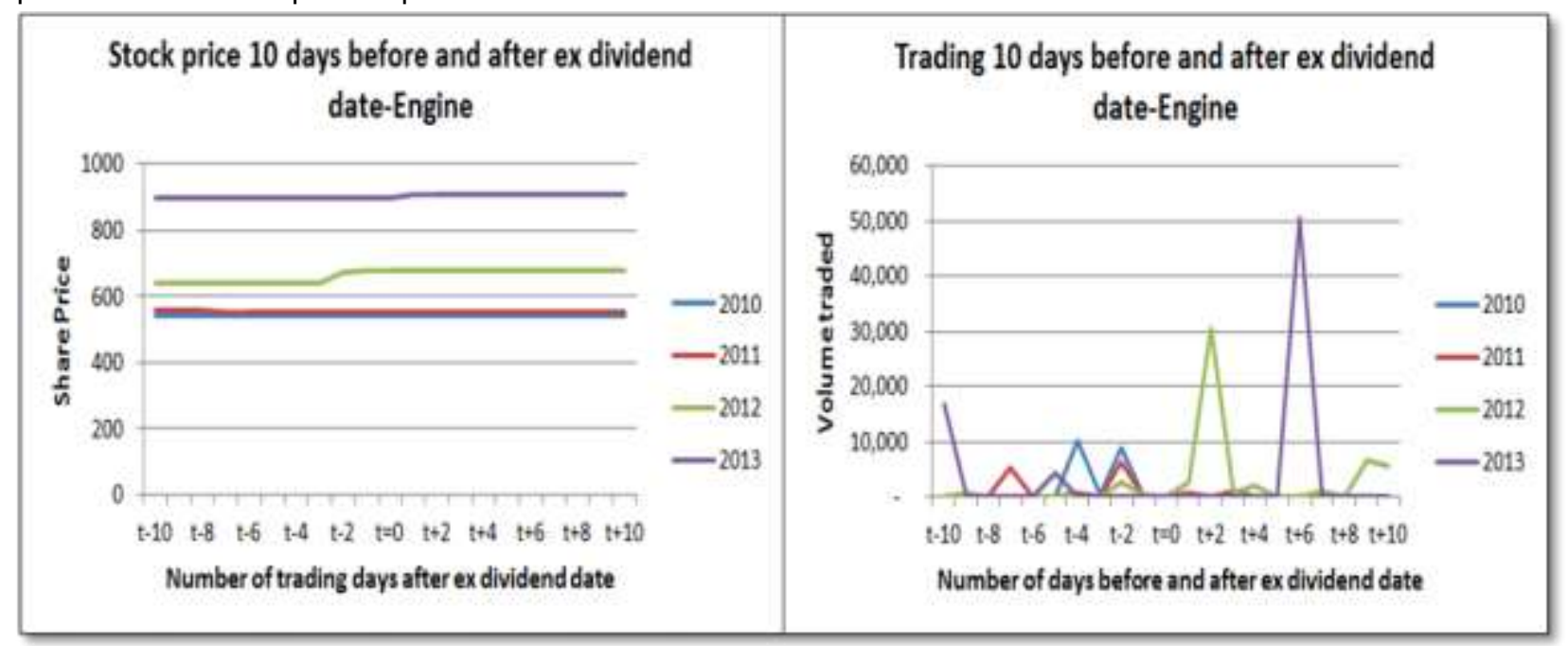

Figure 17: Stock Price and Traded volumes before and after ex-dividend dates for Engen 
Overall the results on the effects of ex-dividend date on stock prices and trade equity volumes show that before or after $t=0$, the stock price either increases or stay the same. This means investors stand a chance to make abnormal returns through ex-dividend trading. Barclays' stock is the only stock to have experienced a decline in price during the period under investigation particularly in 2010. Therefore, the rate of returns (RR) for stock trading during this period can be denoted as $R R>=0$. These findings areconsistent and built on the empirical evidence brought by Yang and Wu (2014) in which they stated that an investor stand to make an abnormal return up to $2 \%$ net of transaction costs when they trade around the ex-dividend date.

\subsubsection{Seasonality analysis}

In this section, the study is looking into determining whether the companies follow a certain trend or cycle in declaring and paying their dividends. For the period under investigation, dividend declaration date is gathered and plotted on a graph to determine the months or period of the year during which most companies declare dividends. The periods are assessed to determine if they provide any strategic benefits. The figure 18 below shows that most companies declare their dividends late in the 4th quarter of the year and on the 1st quarter of the year. Of all the 36 dividend announcement events since 2010, for the ten-company sample, $55.6 \%$ of them were announced between December and March. The remaining $44 \%$ was spread throughout the year. There is a question of why early and late year announcement? Is this a strategic move that provide some catalytic benefits on dividends; it appears there is.

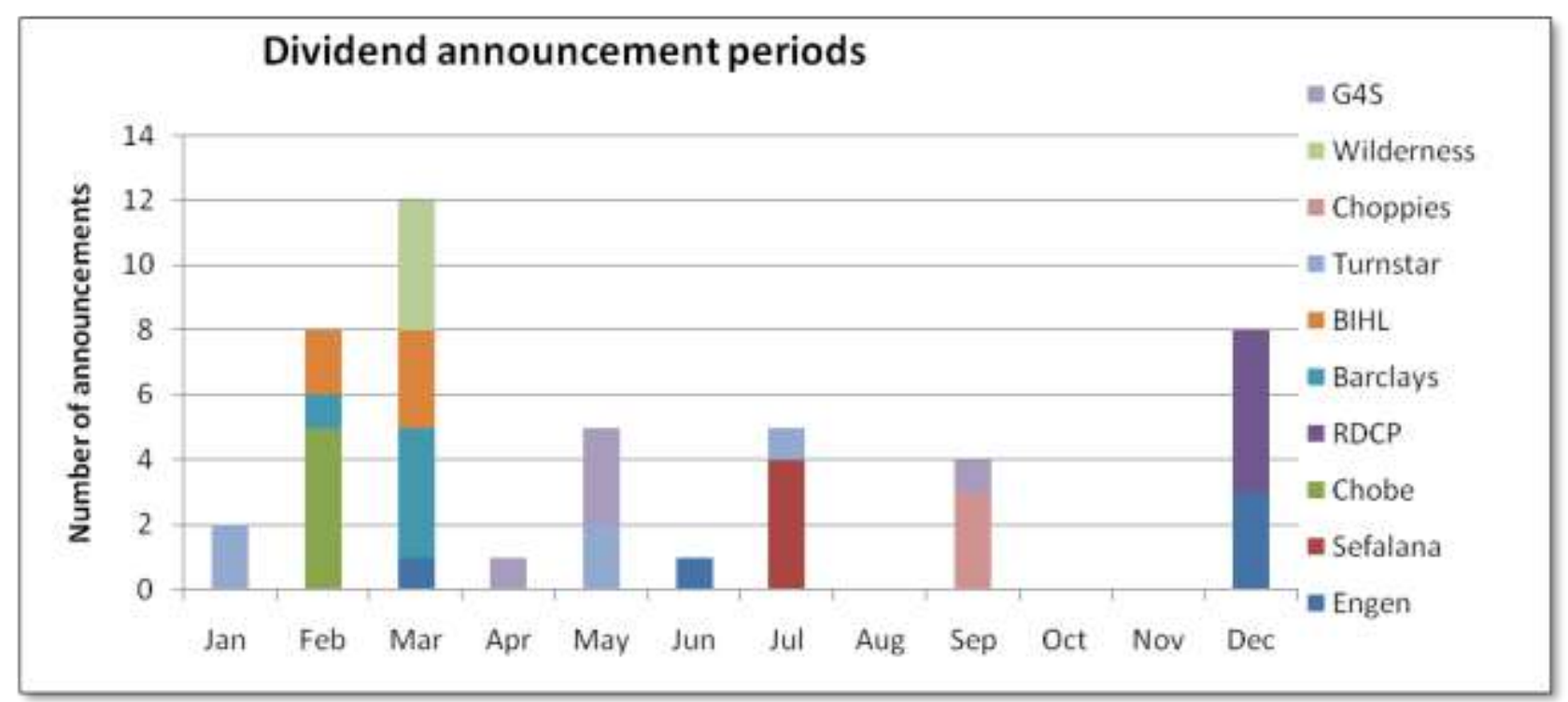

Figure 18: Dividends Announcement Period of Some BSE listed firms

One of the market anomalies, January effect, which was observed by Wachtel (1942), could be a possible explanation for the announcement during this period. The January effect state that prices decline in December and rise again in January than any other period during the year. In his view, this was due to the small size effect because small cap businesses outperformed large cap businesses during this period. The other reason is that many investors sell of their stocks at the end of the year to record losses and get tax benefits, then repurchase their stocks again when the year begins. So based on findings above that dividends influence volumes of stocks traded and to some extend lead to increase in stock price, the announcement of dividends between December and March could be a contributing factor to the January effect. Companies may be making these announcements at year-end to boost demand for their stock, which will drive stock price up early the following year. Stocks may also be appealing to the public to buy so they can receive cash and cover up for their Christmas and holiday spending. This period is, therefore, strategic because it helps fuel the January effect; make the stock attractive, increase its demand and consequently increase the stock price. The figure below shows the graphical presentation of this information for the sampled BSE listed firms.

\section{CONCLUSION}

The main objective of this study is to examine the effect of dividend pay-out on the prices of stock in the Botswana's equity market as well as the effect of traded volumes of such stocks. Other objectives of the research are to determine the optimal pay-out ratio based on the profits of the firm and to determine the optimal time to declare and pay dividends. We use quota-sampling technique to come up with 5 
companies from the 22 domestic listed companies in the Botswana Stock Exchange. The companies under consideration are Barclay Bank, RDCP, Chobe, Engen and Sefalana PIcs. These companies are chosen based on the availability of daily closing trading information for the past five years and easiness to get information to use for our study which includes dividends pay-outs, profits made, volumes trades etc.

The result of this study reveals that there is a direct relationship between dividends announcement, exdividends and volume of stock traded and the stock price in Botswana. Significant changes in volumes of stock traded are observed around dividends announcements and ex-dividends dates (we referred to this 2 period as $t=0$ in our analysis). Effect of announcement is observed when trading spikes up after announcement date, with complimentary positive rate of return (RR) on stock prices, which is equal to or slightly greater than zero, $(R R=>0)$. Abnormal trading is observed before or occasionally after the $t=0$. The conclusion is that before $t=0$, investors position themselves for dividend pay-out, while trading after $t=0$ is assumed to be a sell off period by investors who are not eligible for dividends. Abnormal trading volumes are accompanied by $\mathrm{RR}=>0$. These conclusions are consistent with most of the studies in this area like Yang and Wu (2014), who observed that investors stand to make an abnormal return of up to $2 \%$ net of transaction costs by trading during this period. Capstaff et.al (2004) also observed abnormal returns for investors who traded during this period.

This study also concludes that there is a direct relationship between dividend pay-out ratio and the stock price. Therefore, when the firm increases or reduces dividend amounts, there is a significant effect on stock price. This is consistent with the findings by Fruhan et al. (2013), who stated that companies have to maintain a certain pay-out ratio which they believe is optimal. They suggest that an optimal ratio is between $40 \%$ and $60 \%$. This evidence is complimented by results from our analysis which show that successful firm pay-out ratio is of $63 \%<D P O R<75$, with the outliers. Poor performing firms are in between $4 \%<$ DPOR $<54 \%$, without outliers. Therefore, this study concludes that there is an optimal payout ratio for a firm and management should consider it in their dividend policy decision making.

The study has also concluded that there is a direct relationship between change in dividends and change in dividend per share. An average correlation coefficient of 0.5 was observed between these variables. This moderate uphill correlation coefficient means that whenever there is an increase (decrease) in net profits, investors expect the company to increase (reduce) the dividends.

The conclusion of this study is on the seasonality of dividend announcements. It has been observed that companies do not just make dividend announcement any random times in the calendar year. It showed that about $55 \%$ of dividend announcements were made between December and March. This has been recognised as a strategic move to increase stock demand, a popularity that will eventually translate to higher trading and an increase in prices. This could increase demand for stock since consumers may find dividends attractive source of income to recover from the Christmas and year-end spending. All these will be done to fuel the January effect so that company stock price starts the year trading at a high price.

\section{RECOMMENDATIONS}

Based on the findings of this study, the following recommendations are made:

Firms should adopt a certain dividend pay-out ratio which they consider optimal since this study show that with the optimal pay-out ratio a company can maximise is stock values and benefit its shareholders.

Investors already owning stocks of companies announcing dividends should sell some shares after the announcement date and before ex-dividend date because the finding in this paper suggests that more capital gains can be made during this time as demand, traded volumes and equity prices are found to go up during these periods.

Investors should buy more shares after the ex-dividend date as the finding suggest that after this date people who bought the shares before ex-dividend date now start disposing them off since they now qualify for dividends which means supply may exceed demand and hence lower stock prices. As indicated by the seasonality findings, most companies pay their dividends between December and March. This makes the stocks attractive to investors because of Christmas and festive spending: people usually spend a lot on this holiday and they are likely to buy stocks paying dividends around this time to supplement their budgets. Therefore, companies should take advantage of this wave to increase demand for their stocks. 


\section{REFERENCES}

- Allen, F. and Michaely, R (2002). Pay-out Policy, in George Constantinides, Milton Harris, and Rene Stulz, eds.: North-Holland Handbooks of Economics Elsevier, Amsterdam),

- Al-Malkawi, H.N, Rafferty, M. and Pillai, R. (2010). Dividend Policy: A Review of Theories and Empirical Evidence. International Bulletin of Business Administration, 171-200.

- Carl B. McGowan, J. (2005). The simplified approach to demonstrating the irrelevance of dividend policy to the value of the firm. Applied Financial Economics Letters, 121-124.

- BSE. (2015). Role in Botswana. Retrieved January 25, 2015, from Botswana Stock Exchange: http://www.bse.co.bw/abt_us/role_in_botswana.php

- Kaur, B. S., \& Kaur, P. (2013). Relevance of dividend policy models in Indian NBFC. The Journal of Sri Krishna Research \& Educational Consortium, ISSN 2229-4104.

- Fama, E. (1970). Efficient capital markets: A review of theory and empirical work. Journal of Finance, 383-417.

- My journey to millions. (2014, 6 9).

- Morningstar. (2014). Major shareholder KO.

- HS, V. (2004). What are the 3 major theory of dividend policy?

- Gordon Growth Model. (2014). Retrieved 09 30, 2014, from Investopedia: http://www.investopedia.com/terms/g/gordongrowthmodel.asp

- Tax Preference Theory. (2013, 12 30). Retrieved 09 30, 2014, from Encyclopaedia of Management: http://mfiles.pl/en/index.php/Tax_preference_theory

- Laiboni, M. (2013, 08 02). Dividend policy theories. Word press Blog.

- Elayan, F. A., Jingyu, L., Donnelly, M. E., \& Young, W. A. (2009). Changes to Income Trust Taxation in Canada: Investor Reaction and Dividend Clientele Theory. Journal of Business Finance \& Accounting, 725-753.

- McGowan, C. B. (2005). A simplified approach to demonstrating the irrelevance of dividend policy to the value of the firm. Applied Financial Economics Letters, 121-124.

- Bajaj, M., \& Vijh, A. M. (1995). Trading Behaviour and the Unbiasedness of the Market Reaction to Dividend Announcement. Journal of Finance, 255-279.

- Baker, K. H., Chang, B., Dutta, S., \& Saadi, S. (2012). Why firms do not pay dividends. The Canadian experience. Journal of business finance and accounting, 1330-1356.

- Xu, P., Rui, O. M., \& Kim, S. (2002). Risk Shift Following Dividend Change Announcement: The role of trading. Review of quantitative finance and accounting, 45-63.

- Sharma, R. (2011). Stock Price Behaviour around Dividend Announcement: An event study methodology. XIMB Journal of management, 24-32.

- Capstaff, J., Klaeboe, A., \& Marshall, A. P. (2004). Share Price Reaction to Dividend Announcements: Empirical Evidence on the Signalling Model from the Oslo Stock Exchange. Multinational Journal Finance, 115-139.

- Yang, J. J., \& Wu, T.-H. (2014). PRICE AND VOLUME REACTIONS TO CASH DIVIDEND ANNOUNCEMENTS: EVIDENCE FROM TAIWAN. The International Journal of Business and Finance Research, 83-96.

- Bulan, L., Subramanian, N., \& Tanlu, L. (2007). On the Timing of Dividend Initiations. Financial Management, 31-65.

- Hoover, R. (2014, December 2). Botswana's best 5 stocks of 2014. Retrieved February 25, 2015, from Investing in Africa: http://investinginafrica.net/botswanas-5-best-stocks-2014

- Wachtel, S. (1942). Certain observations on seasonal movements in stock prices. The journal of business of the University of Chicago, 184-193.

- Capstaff, J., Klaeboe, A., \& Marshall, A. P. (2004). Share Price Reaction to Dividend Announcements: Empirical Evidence on the Signalling Model from the Oslo Stock Exchange. Multinational Finance Journal, 115-139.

- Hussainey, K., Mgbame, C. O., \& Chijoke-Mgbame, A. M. (2010). Dividend policy and share price volatility. Journal of risk finance (Forthcoming).

- Baskin, J. (1989). Dividend policy and the volatility of common stock. The journal of portfolio management, 19-25.

- Fruhan, M., Hebard, C., Morrow, J., \& Rahman, N. (2013). Pay-out Ratio: The Most Influential Management decision a company can make. Fidelity Investment LLC. 